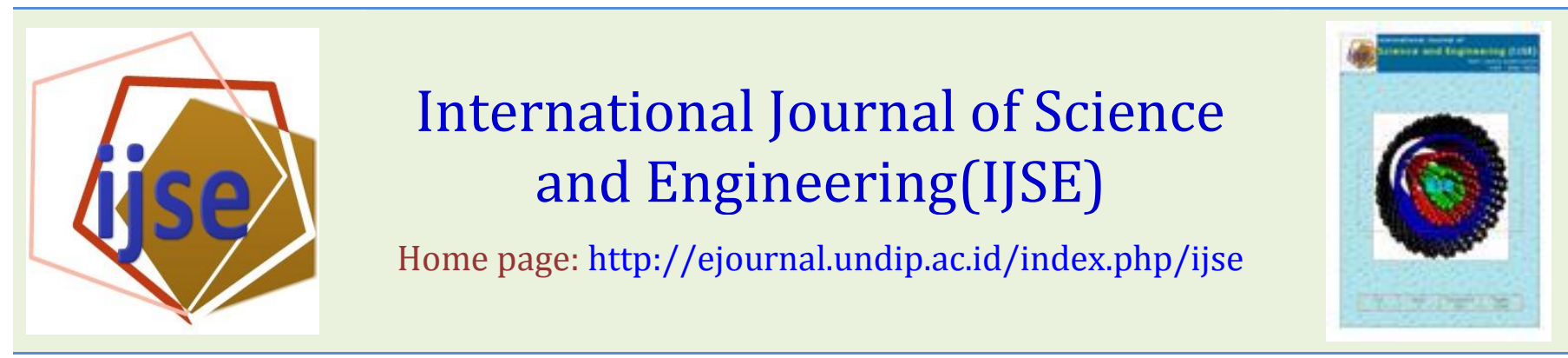

\title{
Community Structure of Macrozoobenthos in Mangrove Ecosystem, Kutai National Park, East Kalimantan
}

\author{
Anugrah A Budiarsa and Samsul Rizal \\ ${ }^{1)}$ Fisheries and Marine Science Faculty of Mulawarman University, Kampus Gunung Kelua Samarinda, East Kalimantan 75123 \\ Email:aditarm83egmail.com
}

\begin{abstract}
Mangrove forest in Kutai National Park (KNP) is considered as nature-protected ecosystem. This forest ecosystem has high productivity ecosystem roles as feeding source, spawning and conservation area for water organism living in this surrounding area such as fishes, crustacean, mollusk and others. At the mangrove floor, mangrove is a benthic ecosystem that utilizes organic material either produced from mangrove itself or land sedimentation. This research was conducted using quadrant transect method with 10 observation stations. Collected data were identified, summed and analyzed. Community structure was analyzed by determining the diversity index, homogenous index and dominant index. The research showed that Makrozoobenthos found at the research location was 17 species which divided into 12 families and 3 classes. The smallest number was found in Lombok Bay (station number 8 ) with 6 species. The largest number was found in Perancis Cape (station number 9) with 15 species. The diversity index of community structure ranged from 1,7 to 2,4. This indicated that the community diversity was at moderate level $(1,5<N<3)$ with good homogenous index $0,8-1$.
\end{abstract}

Keywords - KNP, Mangrove, Makrozoobenthos, Kutai

Submission: May 11, 2014

Correction: June 15, 2014

Accepted: July 08, 2014

Doi: 10.12777 /ijse.7.1.91-94

[How to cite this article: Anugrah A Budiarsa, Samsul Rizal. 2014. Community Structure of Macrozoobenthos in Mangrove Ecosystem, Kutai National Park, East Kalimantan, International Journal of Science and Engineering, 7(1),91-94]. Doi: 10.12777/ijse.7.1.91-94]

\section{INTRODUCTION}

In the ecological or economical perspective, mangrove is considered as an important resource. Mangrove roles as spawning and protection area for several important organisms, renewable wood resource, accumulation area for sedimentation, nutrient and pollutants. Moreover, mangrove also serves as protection against erosion, storm and even tsunami as well as shoreline stabilization on coastal areas (Ayukai et al. 1998, Alongi 2002, 2008, Alongi and Carvalho 2008, Bouillon et al., 2008; Moll 2011).

Mangrove detritus is known to have an important role as a food resource in a decomposer food chain such as macro-invertebrate including sesarmid crab, fiddler crab and gastropoda (Bouillon et al., 2002, Kristensen 2008). Crab had ability to reduce $30-90 \%$ of fallen leaves (Kristensen et al., 2008).

One effort to enrich knowledge concerning mangrove ecosystem is by studying the dynamic of mangrove substrate. This is an important foundation to study the structure and dynamic of a complex mangrove ecosystem. Substrate is an essential living medium for various organisms where the decomposition, grazing and foraging relationship in a food chain were taken place (Hogart, 2007). Hogarth (2007) also stated that mangrove provides environment and nutrient source for marine organism. The root system extends the available surface which provides denser substrate than the surrounding mud substrate, whereas the primary production supplies energy for many organisms. The substrate produced by the root system also serves as medium for photosynthetic algae to grow. Most of these algae are unicellular diatoms. It is also known that blue and green Cyanobacteria are commonly found in almost all the surface of the substrate. Invertebrate community lives in mangrove ecosystem consists of mollusk, Arthropoda, Sipuncula, Nematoda, Nemertean, Platyhelminthes, and Annelida. Mollusk and crustacean dominates benthic fauna community in most mangrove ecosystem. According to Hogarth (2007), the largest abundant and the most diverse of Crustacean was Branchyura or true crab and the dominant families among Brachyura was Grapsidae and Ocypodidae.

Kutai National Park (KNP) is acknowledged as one of Indonesian national park which designed to conserve the Borneo tropical forest ecosystem including the mangrove ecosystem. Kutai National Park has the potential of \pm 
5192,54 ha of mangrove ecosystem. The ecological condition of Kutai NP was good with vegetation density ranging from 967 up to 1567 ind/ha (Budiarsa, 2013). This condition made research on the dynamic of natural mangrove ecosystem become interesting. One of the researches objectives was to observe the benthic organism living in mangrove substrate in Kutai National Park

\section{RESEARCH METHOD}

This research was carried out on March 2012 at 10 observation stations along the mangrove ecosystem edge zone $( \pm 100 \mathrm{~m}$ landward), Kutai National Park, East Kalimantan (Fig. 1). The location name and coordinate of the observation station are shown in Table 1.

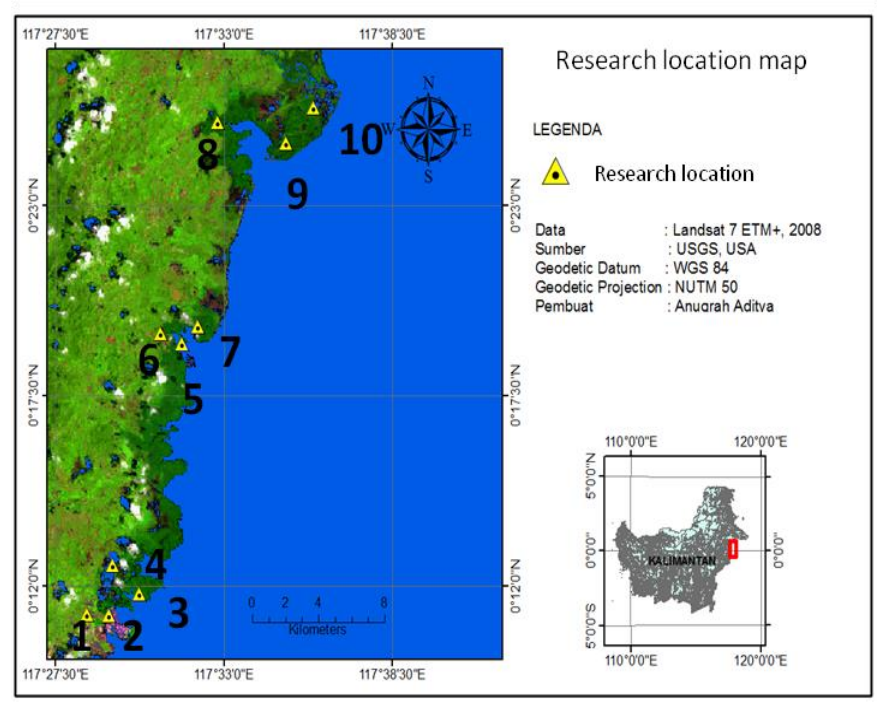

Figure 1. Observation station map

Table1. The location and coordinate of observation station

\begin{tabular}{clrr}
\hline \multirow{2}{*}{ Station } & \multirow{2}{*}{ Location name } & \multicolumn{2}{c}{ Coordinate (UTM) } \\
\cline { 3 - 4 } & & \multicolumn{1}{c}{ North } & \multicolumn{1}{c}{ East } \\
\hline 1 & Bontang 1 & 20962.2 & 555126.32 \\
2 & Bontang 2 & 21965.68 & 557564.84 \\
3 & Pandan Bay 1 & 22588.63 & 556385.88 \\
4 & Pandan Bay 2 & 24048.67 & 558247.59 \\
5 & Kaba Bay 1 & 35096.7 & 559992.64 \\
6 & Kaba Bay 2 & 35631.19 & 558741.66 \\
7 & Muara Sangkima & 36184.91 & 561052.81 \\
8 & Lombok Bay & 45882.33 & 562568.98 \\
9 & Perancis Cape & 45149.95 & 565626.70 \\
10 & Muara Sangatta & 48368.91 & 568294.34 \\
\hline
\end{tabular}

Benthos sample was collected under $50 \mathrm{~cm} \times 50 \mathrm{~cm}$ quadrat size. Benthos sample was then analyzed in the laboratory of Water Quality, Faculty of Fisheries and Marine, Mulawarman University. Data analysis was conducted using the Benthos abundance equation as shown below:

$$
\mathrm{N}=\frac{\mathrm{O}}{\mathrm{A} \times \mathrm{S}} \times 10000
$$

Whereas:

$\mathrm{N}=$ Makrozoobenthos abundance (ind $/ \mathrm{m} 2$ )

$\mathrm{S}=$ Sample collection repetition

$\mathrm{O}=$ Number of makrozoobenthos that had been found

$\mathrm{A}=$ Quadrat area $(\mathrm{cm} 2)$

The next stage was to analyze the community structure based on the diversity $\left(\mathrm{H}^{\prime}\right)$, homogeneity ( $\left.\mathrm{E}^{\prime}\right)$ and the dominant species $(\mathrm{C})$ parameters.

\section{III.RESULT AND DISCUSSION}

In mangrove ecosystem, food web is determined by the detrital food web. At the tropic level of a food web, the position of makrozoobenthos is at the second and or the third level. The productivity of makrozoobenthos is acknowledged as the indicator of environmental quality and productivity in mangrove ecosystem (Owen, 1974). This research found 17 species of Makrozoobenthos which divided into 12 families with 3 classes (Table 1).

Table 2. List of family and species found in Kutai National Park*

\begin{tabular}{cll}
\hline No. & \multicolumn{1}{c}{ Family } & \multicolumn{1}{c}{ Species } \\
\hline \multicolumn{2}{c}{ Crustacea } & \\
\hline 1 & Ocipodidae & Uca forsipata \\
2 & Ocipodidae & Uca lactea \\
3 & Grapsidae & Episesarma sp \\
\multicolumn{1}{c}{ Gastopoda } & \\
\hline 1 & Potamidae & Telescopium telescopium \\
2 & Potamidae & Terebralia sulcata \\
3 & Potamidae & Cerithidea cingulata \\
4 & Potamidae & Cerithidea quadrata \\
5 & Muricidae & Chicoreus capucinus \\
6 & Nerithidae & Nerita lineata \\
7 & Nerithidae & Nerita Fulgurans \\
8 & Assimineidae & Sphaerassiminea miniata \\
9 & Onchididae & Onchidium griseum \\
10 & cerithiidae & Cerithium granosum \\
11 & littorinidae & Littoraria ardouiniana \\
Bivalvia & & \\
\hline 1 & Isognomonidae & Isognomon ephippium \\
2 & Corbiculidae & Polemysoda erosa \\
3 & Archidae & Anadara Antiquata \\
\hline
\end{tabular}

*Primary Data, 2012

The composition of species and individual number of makrozoobenthos found in all research location was $60 \%$ of Gastropoda, 24\% of Crustacea and 16\% of Bivalvia. In detail, Gastropoda consisted of 11 species from 7 families, Crustacea consisted of three species from two families and Bivalvia consisted of 3 species from 3 families (Fig. 2). 


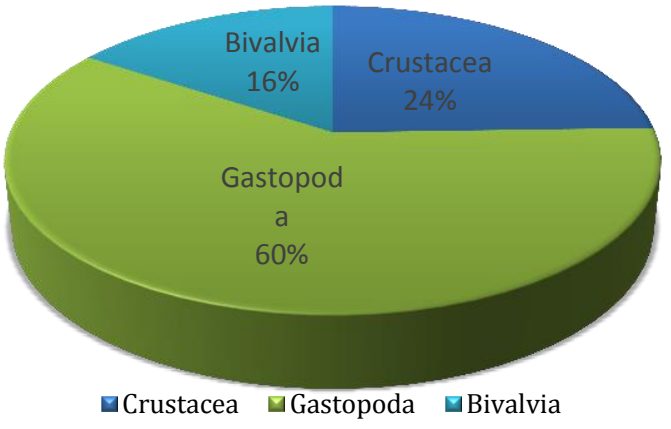

Figure 2. The composition of Makrozoobenthos found in research location
The abundance of Makrozoobenthos from Gastropoda was generally found in mangrove forest with large number of Rhizophoraceae family vegetation. This vegetation commonly dominated the mangrove forest in Kutai National Park (Table 4). This result conformed the finding of Suwondo et al. (2005) and Heriyanto (2005) which stated that large number of Gastropoda lived with Rhizophoraceae vegetation in muddy substrate and found in large colony at area flooded with sea water. This result was found in research located at mangrove forest in Sipora island, Kepulauan Mentawai District (Suwondo et al., 2005) and mangrove forest located across the Sumenep island (Heriyanto, 2005).

Table 3. Species index in mangrove forest of Kutai National Park

\begin{tabular}{|c|c|c|c|c|c|c|c|c|c|c|c|}
\hline \multirow{2}{*}{ No } & \multirow{2}{*}{ Species } & \multicolumn{10}{|c|}{ Location } \\
\hline & & 1 & 2 & 3 & 4 & 5 & 6 & 7 & 8 & 9 & 10 \\
\hline 1 & R. mucronata & 126 & 113.6 & 162.3 & 99.8 & 125.9 & 146.9 & 140.8 & 94.5 & 104.3 & 41.3 \\
\hline 2 & R. apiculata & 94.1 & 145.2 & 64.1 & 137.3 & 107.2 & 86.3 & 100.5 & 165 & 102.8 & 70 \\
\hline 3 & R. stilosa & 20.5 & 0 & 31.7 & 18.2 & 50.2 & 36.9 & 34.0 & 0 & 34.3 & 0 \\
\hline 4 & B. sexangula & 29.4 & 20.5 & 17.2 & 0 & 16.8 & 0 & 0 & 16.08 & 28.0 & 0 \\
\hline 5 & C. decandera & 12.3 & 0 & 0 & 0 & 0 & 0 & 0 & 0 & 0 & 0 \\
\hline 6 & Ceriop tagal & 0 & 0 & 0 & 16.8 & 0 & 0 & 0 & 24.38 & 30.6 & 18.1 \\
\hline 7 & S. alba & 0 & 20.8 & 0 & 27.9 & 0 & 29.91 & 0 & 0 & 0 & 0 \\
\hline 8 & S. caseolaris & 0 & 0 & 0 & 0 & 0 & 0 & 24.7 & 0 & 0 & 0 \\
\hline 9 & Nypa fruticans & 17.7 & 0 & 13.3 & 0 & 0 & 0 & 0 & 0 & 0 & 63.7 \\
\hline 10 & Avicennia alba & 0 & 0 & 0 & 0 & 0 & 0 & 0 & 0 & 0 & 60 \\
\hline 11 & $X$. granatum & 0 & 0 & 11.4 & 0 & 0 & 0 & 0 & 0 & 0 & 25.3 \\
\hline 12 & P. tectorius & 0 & 0 & 0 & 0 & 0 & 0 & 0 & 0 & 0 & 21.6 \\
\hline & $\sum$ Spesies & 6 & 4 & 6 & 5 & 4 & 4 & 4 & 4 & 5 & 7 \\
\hline
\end{tabular}

Source: Primary data, 2012

The fewest number of species was found at Lombok Bay station (8) with 6 species while the largest number was found at Perancis Cape station (9) with 15 species.

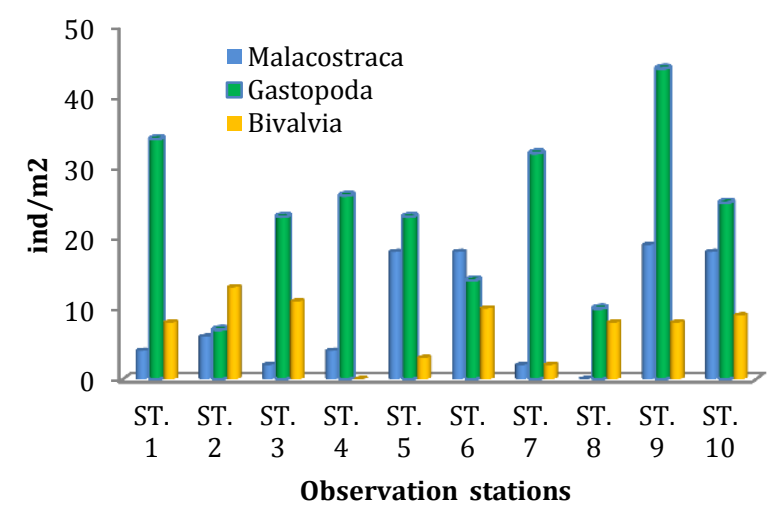

Figure 3. Makrozoobenthos distribution in Kutai National Park

In the Malacostraca class, the largest abundance was Uca forsipata species with $8-12$ ind/m2 while the fewest abundance was Uca lacteal species with 5-7 ind $/ \mathrm{m} 2$. In the Gastropoda class, the largest abundance was Terebralia sulcata with $12-16$ ind $/ \mathrm{m} 2$ while the fewest abundance was Cerithium granosom with 1-3 ind $/ \mathrm{m} 2$. Research also found that Gastropoda class dominated all observation stations with $2-6$ ind $/ \mathrm{m} 2$ of Episesarma species which found at all stations.

Crab from Grapsidae and Ocypodidae was the key component of indo-pacific mangrove ecosystem (Lee, 1998). Ocypodids such as Uca crab represents the mangrove forest floor characteristic and had high density (Hartnoll et al., 2002). Besides, these crabs highly influenced the floor topography of mangrove forest and the composition of micro flora sedimentation $\left(\mathrm{O}^{\prime}\right.$ lafsson \& Ndaro 1997). Important role for Indo-Pacific mangrove ecosystem especially the productivity of primary mangrove was also observed from Searmids (Grapsidae: Sesarminae) (Smith et al., 1991). Barnes (1997) stated that some of Gastropoda attached to hard substrate but some of them also lived in soft substrate such as sand and mud. The habitats of Gastropoda in mangrove forest are mangrove tree, above the mud surface and inside the sediment (Plaziat, 1984). Gastropoda living in mangrove tree could attach on root, stem and leaf and also at dead tree. Some of snails from Gastropoda lived in mangrove area, above the muddy soil, attached to root or stem of mangrove tree. Some of them including Littorina, Cassidula, Cerithidae and others climbed the mangrove three (Dharma, 1988). As one of species living in mangrove forest, Gastropoda can be used as biogeography indicator of mangrove ecosystem productivity (Plaziat, 1984). 
Table 5. Makrozoobenthos community index in Kutai National Park

\begin{tabular}{|c|c|c|c|c|c|c|c|c|c|c|}
\hline \multirow{2}{*}{ Community Structure } & \multicolumn{10}{|c|}{ Observation Stations } \\
\hline & ST. 1 & ST. 2 & ST. 3 & ST. 4 & ST. 5 & ST. 6 & ST. 7 & ST. 8 & ST. 9 & ST. 10 \\
\hline Number of individual/m & 46 & 26 & 36 & 13 & 44 & 24 & 36 & 18 & 71 & 52 \\
\hline Number of species & 9 & 7 & 8 & 7 & 10 & 8 & 9 & 6 & 15 & 11 \\
\hline Diversity ('H) & 1.9 & 1.8 & 1.7 & 1.9 & 2.1 & 2.0 & 1.8 & 1.7 & 2.4 & 2.2 \\
\hline Homogeneity ('e) & 0.9 & 0.9 & 0.8 & 1.0 & 0.9 & 1.0 & 0.8 & 1.0 & 0.9 & 0.9 \\
\hline Domination (D) & 0.18 & 0.19 & 0.25 & 0.16 & 0.13 & 0.14 & 0.21 & 0.19 & 0.11 & 0.13 \\
\hline
\end{tabular}

Source : Primary Data 2012

The environmental condition of Makrozoobenthos habitat can be seen from the community index value (Table 2). The lowest diversity index was 1,7 which found at station number 3 (Pandan Bay 1) and station number 8 (Lombok Bay) while the highest diversity index was 2,4 at station number 9 (Perancis Cape). The differences of diversity were influenced by the number of individuals, kinds of species, homogeneity and the abundance of each species (Odum, 1971). Hughes (1986) stated that high diversity index of Makrozoobenthos occurred when many kinds of species was evenly distributed. On the contrary, low diversity index occurred when the distribution of the species was not evenly distributed. According to the observation result at all stations, it can be seen that the diversity index value ranged at $1,5<\mathrm{N}<3$ which indicated that the community was moderately stable. Moreover, the homogeneity index value was 0,8-1 which considered as a good condition.

\section{CONCLUSIONS}

In this research, 17 species of Makrozoobenthos were found which divided into 12 families and 3 classes. The fewest number was found at Lombok Bay (station number 8) with 6 species, while the largest number was found at Perancis Cape (station number 9) with 15 species. The diversity index of community structure ranged from 1,7 to 2,4 . This indicated that the community diversity was moderate $(1,5<\mathrm{N}<3)$ with good homogenous index $0,8-1$.

\section{Acknowledgment}

The author would like to thank to Ir. Asep Sugiharta, M.Sc as the Head of Kutai National Park Office and Ir. Timur Luri S. M.Si as the Head of Fisheries and Marine Office of East Kutai District. The author would also thank to staffs of UPT.P3KT for their valuable support in providing information and data needed in this article.

\section{REFERENCES}

[1] Alongi DM (2002) Present state and future of the world's mangrove forests. Environmental Conservation 29:331-349

[2] Alongi DM (2008) Mangrove forests: Resilience, protection from tsunamis, and responses to global climate change Estuarine, Coastal and Shelf Science 76:1-13

[3] Alongi DM, Carvalho NA (2008) The effect of small-scale logging on stand characteristics and soil biogeochemistry in mangrove forests of Timor Leste. Forest Ecology and Management 255:1359-1366

[4] Ayukai T, Miller D, Wolanski E, Spagnol S (1998) Fluxes of nutrients and dissolved and particulate organic carbon in two mangrove creeks in northeastern Australia Mangroves and Salt marshes 2:223-230

[5] Barnes, R.D. 1987. Invertebrate Zoology. 5th Edition. B. Sounders College Publishing : pp. $344-377$

[6] Bouillon S, Borges AV, Castaneda-Moya E, Diele K, Dittmar T, Duke NC, Kristensen E, Lee SY, Marchand C, Middelburg JJ, RiveraMonroy VH, Smith III TJ, Twilley RR (2008) Mangrove production and carbon sinks: a revision of global budget estimates. Global Biogeochemical Cycles

[7] Budiarsa A.A, 2013. Mapping and Analysis of Mangrove Forest Damage in Kutai National Park based on Etm Landsat Satellite Data and Vegetation Density. J Ilmu Perikanan Tropis.

[8] Dharma, B. 1988. Indonesian Shells. Penerbit PT. Sarana Graha. Jakarta. $107 \mathrm{hlm}$.

[9] Moll Regine, 2011. Impact of mangrove and agriculture - dominated hinterland on carbon and nutrien biogeochemistri in the Segara Anakan Lagoon, Java Indonesia. Phd Thesis, Bremem University, German.

[10] Hartnoll RG, Cannicci S, Emmerson WD, Fratini S, Macia A, Mgaya Y, Porri F, Ruwa RK, Shunula JP, Skov MW, Vannini731 M (2002) Geographic trends in mangrove crab abundance in East Africa. Wetlands ecology and Management June 2002, Vol 10, Issue 3, pp 203-213

[11] Heryanto, 2005. The Ecology of Mangrove P. Mollusk in Sumenep District, East Java. Technical Report on Botanical. Biological Research Center. LIPI. Page. 141 - 145

[12] Hughes, R.N. 1986. A Functional Biology of Marine Gastropods. The John Hopkins University Press. Baltimore. Maryland. 231 pp.

[13] Hogarth, P. J., 2007. The Biology of Mangroves and Seagrasses. Oxford University Press Inc. New York

[14] Kristensen E., 2008. Mangrove crabs as ecosystem engineers; with emphasis on sediment processes. J Sea Res 59:30-43.

[15] Keshavarz M, E. Kamrani and A.R. Dabbagh, 2012. A Description of Higher Macrobenthic Infaunal Taxa of Mangrove Mud Flats at Khamir Port, Iran. Annals of Biological Research 2012, 3 (2):, Scholars Research Library. Pg. 1029-1043

[16] Lee SY (1998) Ecological role of grapsid crabs in mangrove ecosystems: a review. Mar Freshw Res 49:335-343

[17] Odum, P.E. 1971. Fundamental of Ecology. Sounders College Publishing. USA. $574 \mathrm{pp}$.

[18] O'lafsson E, Ndaro SGM (1997) Impact of the mangrove crabs Uca annulipes and Dotilla fenestrata on meiobenthos. Mar Ecol Prog Ser 158:225-231

[19] Owen T.L., 1974; Handbook of Common methods in Limnology, Institute of environmental studies and department of biology, Baylor University

[20] Plaziat, C.J. 1984. Mollusc Distribution in Mangal. Dr.W. Junk Published. pp.121-143

[21] Robertson, A.I., 1986. Leaf-burying crabs: Their influence on energy flow and export from mixed mangrove forests (Rhizophora spp.) in north eastern Australia. J. Exp. Mar. Biol. Ecol. 102, 237-248

[22] Smith TJ III, Boto KG, Frusher SD, Giddens RL (1991) Keystone species and mangrove forest dynamics: the influence of burrowing by crabs on soil nutrient status and forest productivity. Estuar Coast Shelf Sci 33:419-432

[23] Suwondo, E. Febrita, F. Sumanti, 2005. The Community Structure of Gastropoda in Mangrove Forest, Kepulauan Mentawai District, West Sumatera. Jurnal Biogenesis Vol 2 (1): 25-29. 